\title{
A study on the Growth of Entrepreneurship in India, with respect to the Growth in Foreign Investment, Economic Growth and Financial Development
}

Prof. Syed Kazim, Assistant Professor and E-Cell Coordinator, Acharya Bangalore B School syedkazim@achryabbs.ac.in

\begin{abstract}
Entrepreneurship is the key to India's development. It is important as it utilizes local resources, generating employment and promotes rural development. This paper examines the impact of financial development, economic development and foreign investment on entrepreneurial development measured by production asper Ministry of Micro, Small and Medium Enterprises (MSME) and fixed investment as per MSME for the period of 1997-1998 to 2016-2017. Using Error correction model, the result shows that investment as per MSME is positively influenced by financial development in long run. In short run foreign investment and economic development positively influence fixed investments in MSMEs. Production per MSME was found to be positively influenced by economic development and financial development in long run while in short run none of the selected independent variables influence production of MSMEs.
\end{abstract}

Keywords: Entrepreneurship, Foreign Investment, Economic Growth, Financial Development

\section{Introduction}

Indian economy has developed since liberalization and is attracting foreign investments, its GDP per capita has increased, the stock market capitalization has deepened and these benefits channelizes back to economy. With the development, globalization and information channel penetration marketplace had shrunk creating new avenues for entrepreneurs to grow and exploit the opportunities. With liberalization of economy in 1991 entry barrier have reduced by great deal and economists view growing foreign investment as a resource providing global reach. The stock market and economy have also benefitted through this as foreign investment which in turn makes investment in India a lucrative business. But does this development have benefitted entrepreneurs is the million-dollar question.

Economic development provides with a high standard of economy, investment scenario both domestic and foreign. The stock market sentiment becomes positive creating boom in the market for new investments and innovation which are few determinants of entrepreneurship. This has cyclic effect with development in one develops other which benefits the earlier. This positive sentiment that is developed was much needed for starting an enterprise to counter the risk associated with it. Opportunity, need and ability are the determinants for entrepreneurship (Davidson \& Honig, 2003) economic development, financial growth, investment sentiment and entrepreneurship policy of the state frames the opportunity.

\section{Objective}

To explore the relationship between entrepreneurship development with foreign investment, financial development and economic growth for the period of 1997-1998 to 2016-2017.

\section{Review of Literature}

Development of banking institution that allows firms to obtain formal finance promoting entrepreneurship 


\section{Entrepreneurship and Startups}

is the need of the hour. The improvement in the flow of communication among firms, reduced cost of gathering information and facilitating the diffusion of technological and managerial expertise promote entrepreneurship (Leff, 1978).

Financial system affects the entrepreneurial activity that affects in different ways, financial system chooses the most promising projects after evaluating.Financial system helps in mobilizing funds, financial system allow investor to diversify the risk associated with uncertain innovative activities, and financial system reward to engage in innovation relative to confirmation of existing knowledge. Better financial system stimulates faster productivity growth and growth per capita output. They suggest that government policies toward financial system may have an important causal effect on long term growth (King and Levine, 1993).

Entrepreneurs contribute to economic development in terms of job creation, innovation and external income generation depending upon priorities and different stage of market reform. The authors suggested direct support to SMEs to overcome immediate difficulties to strengthen their potential for development and growth (Smallbone and Welter, 2001).

The causal links between trade, economic growth and inward foreign direct investment in china is investigated. With quarterly data long run relationship found between growth, export, import and FDI. The author finds bidirectional causality between economic growth, FDI and export which reinforce open door policy (Liu, Burridge, and Sinclair, 2002). They examine the links between FDI, financial market and growth considering that financial agents either take up entrepreneurial activity or use wealth to get returns by working for company in the FDI sector. Better financial market provides incentive for FDI. They found that FDI plays important role in the economic growth (Alfaro et. al., 2004).

Firms with less than twenty employees have greatest impact for the decade of 1990's, they suggested that the firm has great potential for future economic development. Also, economic policy changes should be specifically to boost entrepreneurship (Carland and Carland, 2004).

The extent of FII in crowding in or crowding out domestic investments with a panel data of three decades for the developing regions of Asia, Africa and Latin America, they found that FDI has nothing to do with domestic investments for sub period and sub areas. With more analysis they found that FDI was found to crowding out domestic investment particularly in Latin America. FDI was found to be unfavorable to crowd in domestic investment (Agosin and Machado, 2005).

A U-shaped relationship between entrepreneurial dynamics and level of economic development. They suggested that for advanced countries incentive structure should be improved while developing nation should exploit economies of scale, foster FDI and promote management education (Wennekers et. al., 2005).

Entrepreneurship has important role to play in fostering from a predominantly traditional economy to modern economy. With innovation driven growth productivity is increased in advanced countries. selfemployment, startup and credit market determine quantity and quality of entrepreneurship. They found that low entrepreneurial activity contributes to economic stagnation and even developmental gap (Naude, 2008).

\section{Analysis and Interpretation}

For measuring entrepreneurship development two proxy's production as per MSME and investment as per MSME have been taken, for financial development stock market capitalization as percentage of GDP and foreign direct investment as percentage of GDP has been taken. The model can be depicted as

Yt1 $=f($ FDIt, GDPt, MCAPt)

$\mathrm{Yt2}=f(\mathrm{FDIt}, \mathrm{GDPt}, \mathrm{MCAPt})$ 


\section{Entrepreneurship and Startups}

Where Yt1 denotes investment per MSME, Yt2 denotes production per MSME, FDI is foreign direct investment, SMC is stock market capitalization. The econometric models are

$\ln Y t 1=\beta 0+\beta 1|\mathrm{FDIt}+\beta 2| \mathrm{GDPt}+\beta \mid \mathrm{MCAPt}+\mathrm{ut}$ $\operatorname{lnYt} 2=\beta 0+\beta 1|\mathrm{FDI}+\beta 2| \mathrm{GDPt}+\beta \mid \mathrm{MCAPt}+\mathrm{v} \mathrm{t}$

( Where 'I' is logarithmic transformation)

\section{Unit Root Test}

It is essential to look for stationarity of data when dealing with time series regression otherwise it will lead to spurious regression and the result will look good with significant t statistic but there would be no significant relation between the variables. In order to check the unit root presence Augmented DickeyFuller test (ADF) is employed.

\section{Engle and Granger's Cointegration Test}

This concept was first introduced by Granger in 1981; this technique is for testing relationship between two non-stationery time series. Two non-stationery time series are said to be cointegrated if they are nonstationary at level i.e. I (0) but both series are stationary at linear combination i.e. at same differentiating level I ( $n$ ). The linear combination cancels out the stochastic trends of the two-time series; this is tested by ADF test. Running the regression on the raw data and testing for spurious regression the value of $R 2$ should be smaller than $d$ (Durbin Watson) value obtained in the regression as a rule of thumb (Gujarati, 2003) or the residuals obtained must be stationary.

\section{Error Correction Model}

This method was first used by Sargan and later popularized by Engle Granger after correcting for disequilibrium. It states that if two variables are cointegrated the relationship can be expressed as ECM (Gujarati, 2003).

\section{$\Delta \mathrm{X}=\alpha 0+\alpha 1 \Delta \mathrm{Y}+\alpha 2 \mathrm{Ut}-1+\varepsilon \mathrm{t}$}

Where $X$ is dependent variable at first differentiation $Y$ is independent variable at first differentiation ut-1 is lagged value of error term obtained from Engle
Granger cointegration test, $\varepsilon$ t is the white noise. The $\alpha 2$ is expected to be negative to restore $\Delta \mathrm{X}$ to equilibrium (Gujarati, 2003).

\section{Data}

Data were obtained from different sources Foreign direct investment taken for foreign investment (FDI expressed as a \% of GDP) was obtained from UNCTAD, for economic growth GDPPC (gross domestic product per capita) was take from world bank data, stock market capitalization as percentage of GDP was taken as proxy for financial development. For entrepreneurship measurement two proxies are used (a) average investment per MSME (b) average production per MSME these data were taken from annual report of ministry of MSME.

All the values of variables were taken in US dollars at current price.

The ADF unit root test shows that the entire five variables are carrying unit root at level and are stationary at first difference. Ifdi and linvest are significant at 5\%, Imcap and Iprod are significant at $1 \%$ while Igdp is significant at $10 \%$. The results of ADF test shows that the variables are integrated at first order i.e I (1). This shows that cointegration exists among the variables.

\section{Long Run Equation}

The equation that is formed in this paper is linvest $=\beta 0+\beta 1$ In FDI $+\beta 2$ In GDPt $+\beta$ In MCAPt+ut Iprod $=\beta 0+\beta 1$ In FDIt $+\beta 2$ In GDPt $+\beta$ In MCAPt $+v \mathrm{t}$ The results obtained from this is Iprod $=5.4416+0.37084 \operatorname{lgdp}+0.12389 \mid$ mcap + 0.04426 Ifdi

(6.87) (3.22) (2.19) (1.00)

(0.00) (0.0053) (0.0436) (0.3319)

$R 2=0.91 \mathrm{~d}=1.25$

Production as per MSME is found to be influenced by economic development, stock market capitalization however foreign direct investment fails to influence entrepreneurship development. If per capita GDP is increased by $10 \%$ the average 


\section{Entrepreneurship and Startups}

production is also increased by $3.7 \%$ significantly, whereas $10 \%$ increase in market capitalization per GDP increases production of MSME by $1.2 \%$. The Durbin Watson value $d$ is greater than $\mathrm{R} 2$ the long run equation is non-spurious as rule of thumb (Gujarati, 2003).

Linvest $=6.984-0.0827 \mathrm{lfdi}+0.289 \mathrm{Imcap}+0.034 \mathrm{lgdp}$

(3.218) (-0.682) (1.869) (0.109)

(0.0054) (0.504) (0.08) (0.9145)

$R 2=0.2816 d=0.647$

Investment per MSME is influenced by market capitalization at $10 \%$ significance level; however foreign direct investment and economic growth failed to influence investment per MSME. It is found statistically that $10 \%$ increase in market leads to 2.8 $\%$ increase in investment per MSME. The durbin Watson value $d$ is greater than $\mathrm{R} 2$ the long run equation is non-spurious as rule of thumb (Gujarati, 2003).

Both the equationswere tested for multicollinearity variance inflation factor (VIF). Variables with VIF value greater than 10 requires further analysis but here VIF were found to be less than 10 . So, the long run equation was free from multicollinearity.

\section{Short Run Equation}

The short run equations formed in this paper are

$\Delta$ linvest $=\beta 0+\beta 1 \Delta$ InFDIt $+\beta 2 \Delta$ In GDPt $+\beta \ln$ $\triangle \mathrm{MCAPt}+\mathrm{ut}-1+\varepsilon$

$\Delta$ Iprod $=\beta 0+\beta 1 \Delta$ InFDIt $+\beta 2 \Delta$ InGDPt $+\beta$ $\Delta$ InMCAPt + v t $-1+\varepsilon$

Where $\Delta$ is the lagged value at first differentiation of variables, ut- 1 and vt- 1 are lagged value of the error term and $\boldsymbol{\varepsilon}$ is the white noise. The results obtained from this short-term equation are

$\Delta$ lprod $=-0.0697+0.0168 \Delta \mathrm{lnFDIt}+1.443 \Delta \mathrm{InGDPt}$ $+0.04 \Delta$ InMCAPt + -0.603v t-1

$(-1.022)(0.345)(1.56)(0.789)(-2.334)$

(0.3238) (0.7349) (0.1388) (0.4431) (0.035)

$\mathrm{R} 2=0.36 \mathrm{~d}=1.38$
In the short run average production per MSME is not influenced by foreign investments, economic development and market capitalization. The lagged error term has negative coefficient and significant at $5 \%$ as desired for the equation.

$\Delta$ linvest $=-0.234+0.0979 \Delta \mathrm{lnFDIt}+3.02 \Delta \mathrm{ln}$ GDPt +0.017 In $\triangle$ MCAPt -0.238 ut-1

$(-3.06)(1.88)(2.88)(0.29)(-2.306)$

(0.0083) (0.081) (0.012) (0.77) (0.036)

$R 2=0.643 d=1.98$

In the short run investment in MSME is influenced by foreign direct investment and GDP; these variables have immediate and positive effect on investment in MSME. The lagged error term is negative and significant at $5 \%$ as desired for this equation.

\section{Discussion and Conclusion}

Entrepreneurship is getting importance as the current economic situation demands job providers to have a dominant role in nation's economy as India is struggling to provide job and income security to its citizens. Entrepreneurship provides significant role in the global as well as domestic economy by industrializing rural and backward areas, as a supplier of input to large industries, creating employment opportunities. It is key driver which transforms agriculture-based economy to industry based which makes it even more important for India, as it's large percentage of population resides in rural areas which is devoid of basic amenities forcing people migrate from rural areas to urban areas. In 2016-2017 there were 447.73 lakh working enterprise giving employment to 1012.59 lakh people. These have contributed $43 \%$ to Indian exports but only $17 \%$ is contributed to GDP while in OECD nation it contributes to $60-70 \%$ of employment, $55 \%$ to GDP (Ministry of Finance, 2018), despite the importance of entrepreneurship environment for venturing into it is not so favorable in India even though it has improved significantly.

It is argued by economists that foreign investment, economic development and financial development 


\section{Entrepreneurship and Startups}

have catalyzing effect in promoting entrepreneurship. As per findings, average investment on MSME is impacted by financial development, this could be of two reasons, first every entrepreneur wants to expand its business so to transform it to public limited company and raise capital from market which will also reduce the risk on the owner. Second is that since MSME contributes to the input of large industries their growth stimulates the growth of the MSMEs. In short run investment is positively influenced by economic development and financial development. The positive economic and financial environment created motivates entrepreneurial activity to gain from this development.

In the long run economic development, financial development has positive influence on production per MSME. Economic development increases the purchasing power of the people which develops new market for small firms. Small firms which sells to both market or supply to big industries get benefitted by this development and these firms have to produce more. Financial development does in the similar way creating new avenue for investment. In the short run none of the independent variables i.e. financial development, economic growth and foreign investment influence productivity of MSMEs. This is because immediate effect is not felt by the small firms.

Entrepreneurship is an important area of focus for India to provide citizens income and job security. To promote it nation has several programs like PMGSY, entrepreneurship promoting agencies like SIDBI, IDBI etc. but it has failed to deliver unlike other emerging economies like China, Morocco etc. The business environment should be made conducive to entrepreneurship policies have to be drafted which attracts foreign investments, promote economic and financial investment.

The researcher has analyzed the effect of foreign investment, economic development and financial development, on entrepreneurial development measured by production and investment. Using two steps of Engle and Granger because of the small size of sample and the number of parameters to be estimated. The result shows that production is positively affected by economic development and financial development in the long run while in the short run production per MSME is not influenced by either of the variables selected as entrepreneurs look for long term benefit to start entrepreneurship or increase production.

\section{References}

1 Agosin, M. R., \& Machado, R. (2005). Foreign investment in developing countries: does it crowd in domestic investment?. Oxford Development Studies,33(2), pp 149-162.

2 Alfaro, L., Chanda, A., Kalemli-Ozcan, S., \& Sayek, S. (2004). FDI and economic growth: the role of local financial markets. Journal of international economics, 64(1), pp 89-112.

3 Carland, J., \& Carland, J. (2004). Economic development: Changing the policy to support entrepreneurship. Academy of Entrepreneurship Journal, 10(2), pp 104-114.

4 Davidsson,P., \& Honig, B. (2003). The role of social and human capital among nascent entrepreneurs. Journal of business venturing, 18(3), 301-331.

5 Gujarati, Damodar. 2003. Basic Econometrics. New York: McGraw Hill

6 King, R. G., \& Levine, R. (1993). Finance, entrepreneurship and growth. Journal of monetary Economics, 32(3), pp 513-542.

7 Leff, N. H. (1978). Industrial organization and entrepreneurship in the developing countries: The economic groups. Economic development and cultural change, pp 661-675.

8 Liu, X., Burridge, P., \& Sinclair, P. J. (2002). Relationships between economic growth, foreign direct investment and trade: evidence from China. Applied Economics, 34(11), pp 14331440. 


\section{Entrepreneurship and Startups}

9 Ministry of Finance. (2018). The inter-ministerial committee for boosting exports from the MSME sector. Retrieved from http://dgft.gov.in/exim/ 2000/imc-EXPORT-sme.pdf on 10 July 2014.

10 Naude, W. (2008). Entrepreneurship in economic development (No. 2008/20). Research Paper, UNU-WIDER, United Nations University (UNU).
11 Smallbone, D., \& Welter, F. (2001). The role of government in SME development in transition economies. International Small Business Journal,19(4), pp 63-77.

12 Wennekers, S., Van Wennekers, A., Thurik, R., \& Reynolds, P. (2005). Nascent entrepreneurship and the level of economic development. Small business economics, 24(3), pp 293-309. 